\title{
PURCHASING BEHAVIOR OF RICE CONSUMERS AND POTENTIAL FOR RICE BRANDING IN SRI LANKA
}

\author{
R.A.S.S. Ranaweera ${ }^{1}$, Y. M. Wickramasinghe ${ }^{1}$ and K.S. Karunagoda ${ }^{2}$ \\ Faculty of Agriculture, Rajarata University of Sri Lanka, Puliyankulama, Anuradhapura 1. \\ Socio Economics and Planning Center, Department of Agriculture, Peradeniya².
}

\begin{abstract}
Branding of agricultural products has confined only to several processed products like meat and dairy products and rice. This study attempts to examine the factors that the consumer considers in purchasing rice, present status and future prospects for rice branding in Sri Lanka. A field survey was conducted with 45 paddy farmers and 45 rice consumers in Anuradhapura district and a purposive sample of 10 rice millers in Gampaha district. A SWOT analysis was done in order to identify strengths and weaknesses of rice branding.
\end{abstract}

Results indicated that grain color, past experience with the brand, extent to which the grains were polished, level of parboiling, proportion of broken grains, smell, stickiness, health reasons, grain type,cleanliness and keeping quality of cooked rice are the attributes that has governed the purchasing decision of the consumer. Consumer's perceived quality is also important to consider as they pay a price premium for the brand based quality.

Millers should develop strategies such as the production of new brands of rice to motivate paddy producers. Millers'strengths should be furthered by encouraging them to introduce new brands. Weaknesses of the miller could be transformed to strengths by presenting rice under renowned brands. Weaknesses of the consumer could be avoided through proper brand communication while the weaknesses of the farmer could be avoided by allowing them to enjoy benefits of branding. So, the prevailing opportunities in Sri Lanka are favorable to promote rice branding.

Key words: rice branding, perceived product qualities, brand promises, brand loyalty

\section{INTRODUCTION}

Per capita consumption of rice in Sri Lanka is 100 kilo grams per annum and rice supplies $45 \%$ and $40 \%$ of per capita requirements of calories and proteins respectively. Approximately $28 \%$ of consumption expenditure of an average Sri Lankan person is spent on rice. Nearly $34 \%$ of the total land area of the 
country is being allocated to paddy production and the total number of families engaged in paddy production is around 1.8 million. This sector generates employments for $25 \%$ of the national labor force. The sector's contribution to the Gross National Production (GNP) was $2.6 \%$ in year 2003(CBSL, 2004). Paddy market in Sri Lanka is nearly perfectly competitive while rice (milled / processed or value added paddy) market is not competitive. Influences of paddy millers and intermediaries plus low level of awareness of the consumer are the main reason to prevail a non competitive rice market. As a result, paddy farming has become an enterprise with low profits whike production and marketing of rice has become a financially attractive investment (Abeyratne, 1990, CBSL, 2004 and Weerhewa, 2002). Product branding is one of the alternatives available to maintain a competitive market.

\section{Product branding}

An agricultural product like rice could be branded based on the qualities of the varieties even though rice branding in Sri Lanka is based on the physical appearances of the rice grain such as grain size (c.g. Samba and $\mathrm{Nadu}$ ) and grain color (e.g. white and red ). In general, Sri Lankan producers supply rice to the market as a generic product, except few millers who supply rice under their brand names. Branding can create consumer loyalty for the product by differentiating products (Kottler and Keller, 2005) while giving more advantages to the producer in the long run. (Sheimp, 1997). Therefore, market for a particular brand could be analyzed in terms of the number of consumers in each category and strategies could be developed to enhance the brand loyalty among members of a particular group of consumers. Analyzing the role that the brand plays and can play in securing greater loyalty across the business could be treated as a starting point for integrated brand communication (www.interbrand.com). Brand management is a process of making and keeping a promise with the customer (Brook, 2002). Brand loyalty could also be influenced by cultural, social and professional factors.

Product is what the firm is making and brand is what the consumer is buying. Brands are examined through their components, parts, brand names, logo, design, packing and image recognition (Kapferer, 1992). Consumer response to different brand is influenced by brand knowledge (Murphy, 1992). Brand portfolio is a set of all brands lines that a particular firm offers for sale in a particular product category (Kottler and Keller, 2005). Creation and maintaining a good brand name is invaluable to the producer because it generates consistent sales volume and revenue, commands a large margin and provides a platform to introduce new brands (Sheimp, 2000). 


\section{Rice branding adopted in Sri Lanka}

Even though product branding has created a high competition for processed agricultural products, branding of generic products like rice, sugar, dhal etc. is very limited and few large scale producers supply branded rice to the whole country. Regardless the scale of operation all rice producers have adopted a common branding strategy for rice, that is the producer's name plus the grain type (eg. Nipuna Samba). In this case Nipuna is the name of the producer while Samba is the grain type. Branding based on rice variety will be a better way as it maintains brand identity and variety related qualities. Branding rice by popular varieties and by area of production through crop zoning is also ideal because such branding exists in Sri Lanka for several fruit varieties.(DOA, 2006) e.g. Bibile - Sweet orange, Nawala - pineapple and so on.

All stakeholders associated with paddy and rice production and marketing, and rice consumption could be benefited through branding. As a result of branding, farmers will get better marketing opportunities for selected paddy varieties and will receive better farm gate price for that product. Then a sustainable collective market system or value chain will develop and it will reduce the price uncertainty faced by the producer. Brand name is an intangible asset to the miller as it is useful in getting the demand for the product raised through consumer loyalty. It will also help the consumer to choose a brand from the increasing number of competitive brands while reducing the risk of choosing a wrong brand.

This study examines factors that consumer considered in purchasing rice, the present status of rice branding and future prospects for rice branding in Sri Lanka.

\section{MATERIALAND METHODS}

This study used both primary and secondary data. Secondary data were extracted from available documents while prtmary data were gathered through a field survey conducted in Anuradhapura and Gampaha districts in 2007. Indiscriminately selected samples of 45 paddy farmers and 45 ricc consumers from Anuradhapura district and a purposive sample of 10 rice millers from Gampaha district were interviewed during the field survey, Data collected from different sources were triangulated whenever possible to ensure their validity. A SWOT analysis was performed to understand the present status and future prospects of rice branding.

\section{RESULTS AND DISCUSSION}

\section{Factors contributing to rice purchasing}

The sample included rural, semi - urban and urban consumers of the district. These categories were included into the sample because their income levels, food habits and life styles are different. Average 
monthly incomes of three categories of consumers included in this study are presented in Table 1 and rural people are the ones with the lowest family income.

Table 1. Socio economic features of the consumers

\begin{tabular}{lcc}
\hline Consumer category & Frequency (\%) & Av. Monthly income (Rs.) \\
\hline Rural & 22 & $<15,000$ \\
Semi- urban & 40 & $15,001-30,000$ \\
Urban & 38 & $>30,000$ \\
\hline
\end{tabular}

Study also revealed that nearly $87 \%$ of the rural consumers are daily wage earners because agricultural income alone is insufficient to meet the monetary obligations of their families. People do purchase different quantities of rice at different time intervals depending on their incomes.

Rural consumers have purchased $1-2 \mathrm{Kg}$. of rice at a time, and they have purchaser rice daily or on every other day. Their financial situation does not permit them to go for bulk purchasing. These consumers have not created a demand for small rice packets of 5 or $10 \mathrm{Kg}$ in size. Semi-urban consumers have purchased their monthly rice requirements in one or two purchases. Urban consumers have purchased their monthly rice requirements in one visit as these people are busy and rich. (Table 2).

Results of the study do not indicate clear relationships between income and profession of the consumer and his preference to rice brands. Being an essential commodity, price elasticity of rice is low and so price was not a serious concem of the consumer when they purchased rice. Free from sand and stones, past experience with a brand, perceived quality parameters ( grain color, degree of polishing, smell, stickiness, content of broken grains, and keeping quality of cooked rice) health reasons and rice type are the key factors considered by the consumers when they purchased rice. Seventy five percent of the consumers are with the opinion that the rice prices prevailing in the market are fair. Consumers with low incomes ( $41 \%$ of the sample) have purchased in small quantities of rice supplied in large packs (lable 3).

Table 2. Quantities of rice purchased and intervals of purchasing

\begin{tabular}{lll}
\hline $\begin{array}{l}\text { Socio economic } \\
\text { category }\end{array}$ & $\begin{array}{l}\text { Rice Purchasing } \\
\text { frequency }\end{array}$ & $\begin{array}{l}\text { Avg. quantity of rice } \\
\text { purchased at a time }\end{array}$ \\
\hline Rural & Daily / every other day & $1-2 \mathrm{Kg}$. \\
Semi - Urban & Once or twice a month & $50 \%-100 \%$ of the \\
& & $\begin{array}{l}\text { monthly requirement } \\
\text { Urban }\end{array}$ \\
\hline
\end{tabular}


Nearly $80 \%$ of the consumers have decided the rice type to be purchased considering their health conditions / nutritional value. One fifth of the respondents are with the opinion that the rice with a red pericarp is rich in nutritive value. On the other hand, people who consume white rice ( $80 \%$ of the respondents) believe that polished long grained white rice is superior in nutritive value. However, only $40 \%$ of the consumers have . considered the grain color when they purchase rice.

\section{Table3. Buying behavior of rice}

\begin{tabular}{cl}
\hline $\begin{array}{c}\text { Reporting } \\
\text { frequency (\%) }\end{array}$ & $\begin{array}{c}\text { Quantity of rice purchased } \\
\text { at a time }(\mathbf{K g})\end{array}$ \\
\hline 41 & Less than $5 \mathrm{Kg}$. \\
27 & $10 \mathrm{Kg}$. packs \\
09 & $05 \mathrm{Kg}$. packs \\
18 & 10 or $05 \mathrm{Kg} \cdot$ packs \\
05 & More than $10 \mathrm{Kg}$. \\
\hline
\end{tabular}

The consumer is expecting rice that is sufliciently parboiled, properly polished, less sticky and free from external matters as high quality rice. So, miller should pay sufficient attention to produce such rice brands.

\section{Benefits of branding}

Study revealed that around $35 \%$ of the consumers indicted that they have a preferred brand along with one or two substitute brands and they have purchased other brands with perceived quality in the absence of the preferred brand. Another $47 \%$ of the consumers indicated that they are having their favorite brands and they purchase only small quantities of another brand when the preferred brand is out of stock. Some other group of consumers (14\%) mentioned that they have no favorite brand and the balance ( $4 \%$ of the consumers) stated that they are not in a position to develop a loyalty to a particular type of rice as they have to consume the rice provide to them under the poverly alleviation program of the government because they are the beneficiaries of the "Samurdlii" program. This information reveals that rice brands are gaining their popularity among customers over time and creating consumer loyalty to different brands. It was also found that the consumer awareness on different rice brands available in the market is low as rice millers have taken minimum efforts to provide relevant information. Millers are not worried bothered to promote their brands as rice market is not competitive on one hand, rice is the staple diet of the people of Sri Lanka on the other: Hence, the government should encourage millers to print basic information that are useful to consumers on rice bags because such market information is beneficial to the consumer to make purchasing decisions. In 
addition to that, providing such information is the responsibility of the miller and free access to product characteristics is a right of the consumer under the Consumer Protection Act. . Mere provision of this information will not be effective unless the consumer is aware of the information. Therefore, an awareness campaign should be launched along with a program to release product characteristics.

Millers have branded their products in order to gain consumer loyalty, to expand the market share and to meet certain legal obligations. Study revealed that each miller is having a deinarcated market segment or a large group of consumers to serve. Survey discovered that millers are enthusiastic to produce branded rice because branding has increased their revenues. They further stated that, there is a high demand for packs of $5 \mathrm{~kg}$ and $10 \mathrm{Kg}$ in size in addition to the large packs (50Kg.).

\section{Present status and future prospects of rice branding}

Study revealed that all consumers are concerned about brand regardless the quantity purchased. Farmers' willingness to supply paddy to miller facilitates the miller to commence rice production. Efficient millers have got their rice brands well established in the market and consumers are also willing to pay a price premium for the brands with high quality. An increase in consumer income, rural urban migration and population growth that could occur over time will increase demand for rice of popular brands. So, there is a potential to introduce high quality rice brands in to the local rice market. Not providing necessary details of rice varieties and low attention paid by the millers to promote their rice brands are weakness of the present system of rice marketing. Under these circumstances the consumer has to choose a brand of rice out of several brands without a complete knowledge about all brands available in the inarket Millers have not developed a mechanism to motivate the farmer to produce paddy of popular varieties while assuring a future market for the product. Competitiveness in the rice market could be increased by promoting different millers to introduce new brands of rice in order to create an environment in which consumer can choose among different brands. Millers could assure the uninterrupted supply of their popular brands by assuring a future market for the paddy produced by the farmer through the introduction of production contracts. Such activities would be beneficial to all three parties engaged in paddy and rice marketing. As there are favorable agricultural policies in Sri Lanka the production of rice in popular brands would be an easy as well as a beneficial task.

\section{Strengths and Weaknesses of rice market}

In order to identify strengths, weaknesses, opportunities and threats a SWOT analysis was done and findings of the analysis are presented in Table 4. 
Possibilities for the high degree of market segmentation could affect adversely on existing brands. Possibility to quit paddy production by farmer in response to ever increasing input prices is another threat that the rice producers (millers) have to face. Future possibility to change their popular brands by consumers is a threat to individual miller but not to the whole industry. Millers'strength should be furthered by encouraging them to introduce new brands because their strength is necessary in establishing and maintaining of good brands. Weaknesses of the consumer could be avoided through branding and proper communication. Weaknesses of the miller could be translated to strengths by presenting and allowing them to enjoy benefits of branding. Prevailing opportunities in Sri Lanka are favorable to promote rive branding.

Table 4. Results of the SWOT analysis

\begin{tabular}{|c|c|c|c|}
\hline Strengths & Weaknesses & pportunities & Threats \\
\hline $\begin{array}{l}\text { Consumer } \\
\text { High bargaining } \\
\text { power } \\
\text { Increased income }\end{array}$ & $\begin{array}{l}\text { Possibility to } \\
\text { mislead by traders }\end{array}$ & $\begin{array}{l}\text { High availability of } \\
\text { different rice } \\
\text { varieties }\end{array}$ & $\begin{array}{l}\text { Switching on } \\
\text { to new brands }\end{array}$ \\
\hline $\begin{array}{l}\text { Millers } \\
\text { Consumers' } \\
\text { preparedness to pay } \\
\text { extra for good quality } \\
\text { rice. } \\
\text { Well established brand } \\
\text { names : }\end{array}$ & $\begin{array}{l}\text { Not mentioning the } \\
\text { product attributes, } \\
\text { rice variety etc., on } \\
\text { the rice pack }\end{array}$ & $\begin{array}{l}\text { High brand loyalty } \\
\text { of customers } \\
\text { Farmers' } \\
\text { willingness to enter } \\
\text { in to supply } \\
\text { agreements with } \\
\text { millers. }\end{array}$ & $\begin{array}{l}\text { High levels of } \\
\text { market } \\
\text { segmentation } \\
\text { High levels of } \\
\text { consumer } \\
\text { segmentation }\end{array}$ \\
\hline $\begin{array}{l}\text { Farmer } \\
\text { Ability to maintain a } \\
\text { continuous supply of } \\
\text { paddy for milling }\end{array}$ & $\begin{array}{l}\text { Low attention paid } \\
\text { to maximize profits } \\
\text { Believe that farming } \\
\text { is an unprofitable } \\
\text { venture. }\end{array}$ & $\begin{array}{l}\text { Favorable policics } \\
\text { of the government }\end{array}$ & $\begin{array}{l}\text { Increasing cost } \\
\text { of production }\end{array}$ \\
\hline
\end{tabular}

\section{CONCLUSIONS}

Amount of rice purchased by a consumer is determined directly by the income of the consumer. Profession of the consumer bears no direct relationship with the brand preference and the type of rice purchased. Past experience with a brand, color of pericarp, level of processing (extent to which the grain is polished), keeping quality after cooking, health reasons and grain type are the factors that consumer had considered in purchasing rice. Brand / product portfolio should be selected according to targeted segment of the population. Rice millers should promote rice varieties demanded by their target markets. 
Keeping brand promises through quality maintenance and proper delivery of the product are important in retaining the consumer. Consumer perceived quality is also very important because consumer decides to pay a premium price for the brand based on quality. Properly defined brand names and maintaining product quality will be permit charging a premium price. If producers go for variety based branding they will be able to leverage on different qualities with different varieties for different prices. There is an increasing demand for branded rice in the market and benefits derived from increased demand could be delivered to farmer. Millers should be motivatedło provide all relevant information of different brands to the consumer.

\section{REFERENCES}

Anon. (2004). http//www.interbrand.com. Retrieved in July, 2004.

Abeyratna, F.E, W.G. Somaratne and Wickramaarachchi. (1990) "Efficiency in rice production and issues relating to protection". Sri Lanka Journal of Economics, Vol.. i(i):16-25

Brook J. (2002) The brand insight. http// www.com.uk, retrieved in July, 2006.

Central Bank of Sri Lanka. (2004) Annual report, 2003. Central Bank of Sri Lanka, Colombo.

Department of Agriculture. (2006) Achieving better markets for agricultural produce through branding,

Proposal and activity plan (unpublished). Department of Agriculture Peradeniya

Integrated Brand communication (2004) Inter Brand Canada Inc,. http// www.interbrand.com, retrieved in July, 2006.

Kapferer, J.N. (1992) Strategic brand management. New approaches to creating and evaluating brand quality, $2^{\text {nd }}$ edition, Kogan publisher, USA.

Kottler, P., and K.L. Keller. (2005) Marketing Management, $12^{\text {th }}$ edition, New Jersey: Prentice Hall Inc., USA.

Murphy, J.M. (1992) Branding, A Key Marketing Tool, $2^{\text {nd }}$ edition, London: The Mc Millan Publication ltd., London.

Sheimp, T.A.(2000) Advertising, promotion and supplementary aspects of integrated marketing communication, $4^{\text {th }}$ edition, Harsourt Publishers, USA.

Werahewa. J, Gunatilaka, H.M. and Petiyagoda, H. (2002) "Future of paddy farming in Sri Lanka: Comparative advantages, scale and rural poverty', Sri Lanka Economic. Journal, Vol.3(2):140144. 